\title{
Factors associated with the distribution and size of Adelges abietis (Homoptera: Adelgidae) galls on a several years old spruce (Picea abies) plantation
}

\author{
Sebastian Pilichowski, Damian Pazio \& Marian J. Giertych
}

\begin{abstract}
Pilichowski, S., Pazio, D. \& Giertych, M. J. 2014: Factors associated with the distribution and size of Adelges abietis (Homoptera: Adelgidae) galls on a several years old spruce (Picea abies) plantation. - Entomol. Fennica 25: 161-169.

The eastern spruce gall adelgid (Adelges abietis) is a homopteran insect related to aphids. It forms pineapple-like pseudocone galls on Norway spruce (Picea abies) shoots, which are often deformed by them. The factors responsible for gall distribution within a tree crown are not clear. We investigated the distribution of galls in crowns on a spruce plantation. We assumed that the number and size of galls is dependent on the size of the tree, position on the crown, the type of shoot and its placement relative to the compass points. We also counted the larval chambers and related their number with gall size. We demonstrated that the largest galls are in the upper part of the crown and on the lateral shoots, and the number of chambers is closely related to the size of the galls. The level of shoot embrace has a significant impact on shoot deformation.
\end{abstract}

S. Pilichowski \& D. Pazio, University of Zielona Góra, Faculty of Biological Sciences, Prof. Z. Szafrana 1; 65-516Zielona Góra, Poland; E-mails: s.pilichowski @wnb.uz.zgora.pl, \&damiandp1@wp.pl

M. J. Giertych, University of Zielona Góra, Faculty of Biological Sciences, Prof. Z. Szafrana 1; 65-516 Zielona Góra, Poland; and Polish Academy of Sciences, Institute of Dendrology; Parkowa 5; 62-035 Kórnik, Poland; E-mail: giertych @man.poznan.pl

Received 10 January 2014, accepted 4 July 2014

\section{Introduction}

Adelgids (Homoptera: Adelgidae) induce growth and development of galls made of the host-plant tissues and they often present complex life cycles (Havill \& Foottit 2007, Redfern 2011a, b, Sano \& Ozaki 2012). Eastern spruce gall adelgid (Adelges abietis Linnaeus syn. Sacchiphantes abietis Linnaeus) infests some spruce species (Picea) and produces pineapple-like galls which deform shoots (Jaśkiewicz et al. 2002, Flaherty \& Quiring 2008, Kosibowicz 2008, Redfern 2011b).
Accordingly, adelgids are undesirable guests of tree plantations, nursery-gardens and natural conifer populations, because they decrease the quality of the trees by deforming the shoots. Moreover, they may lead to significant weakening and death of their hosts (Kirkeby-Thomsen 1998, Chilima \& Leather 2001, Jaśkiewicz et al. 2002, Evans \& Gregoire 2007, Miller-Pierce \& Preisser 2012, Sano \& Ozaki 2012, Ravn et al. 2013). Some adelgid species have been introduced world-wide in many regions. As a consequence, some naturally occurring tree species have started 
vanishing (Evans \& Gregoire 2007, MillerPierce \& Preisser 2012, Ravn et al. 2013). One example is Adelges tsugae Annand destroying Tsuga canadensis (L.) Carrière in North America (Evans \& Gregoire 2007, Miller-Pierce \& Preisser 2012). Mass gradations of A. abietis in the lower and upper subalpine forest of the Izera Mountains (Poland) result in the devastation of spruces (Kosibowicz 2008).

The factors responsible for gall induction have been studied for a long time. Among them, two groups of stimuli were taken into consideration: the mechanical (plant tissue penetration with mouthparts, ovipositor, etc.) and chemical stimuli. Many authors usually consider the chemical stimuli as gall-inducing but there are also results suggesting joint effect of both stimuli. It is highly probable that Adelges cooleyi Gillette induces galls chemically by injecting a stimulus to the host's vascular system (Sopow et al. 2003). Thus, the authors reject the mechanical stimulus hypothesis. Other authors investigated the presence of galls in the light of hypotheses linked to the vigor of plant modules as Optimal Module Size Hypothesis, Plant Vigor Hypothesis, and Dose-dependent Hypothesis (Fidgen et al. 1994, McKinnon et al. 1999, Flaherty \& Quiring 2008).

It is obvious that galls differ in size. Independently of the decisive factor, another question was posed whether the size is connected with the quality of inducing insect. Sopow and Quiring (2001), after examination of Adelges cooleyi, Pineus pinifoliae Fitch and Pineus similis Gillette concluded that large galls produce more offspring. Adelges japonicus Monzen larvae inhabiting the galls stimulate their swelling - the more larvae within a gall, the larger the gall (Ozaki 2000). However, there exists a critical size of the gall, after which competition between larvae within a gall increases. Other factors probably affecting the gall development are abiotic ones, such as temperature and insolation. A result of the mentioned interactions is the vertical and horizontal distribution of galls within tree crowns. Some authors claim that the higher gall abundance in the upper crown layer is a response to the light and temperature conditions, which may lower survival of $A$. tsugae during summer and enhance it during winter (Evans \& Gregoire 2007). On the other hand, results for $A$. abietis on white spruce
(Picea glauca (Moench) Voss.) shoots show that the galls occur most commonly in the middle layer of the tree crown (McKinnon et al. 1999), and on medium-sized modules. Fidgen et al. (1994) found that $A$. abietis galls developed in the middle layer of crowns of the open-grown white spruces were most frequent. Chilima and Leather (2001) did not find any evidence for height-preferences of Pineus boerneri Annand within Pinus kesiya Royle ex Gordon crowns. Studies on the spatial distribution of Cynips quercusfolii Linnaeus (Hymenoptera: Cynipidae) on Quercus robur L. suggest preference for the upper tree crown (vs. the lower crown), especially on medium-sized trees (Giertych et al. 2013). The authors supposed that this is connected with the availability of nutrients.

Monoterpens, phenols and tannins are, among other purposes, meant to defend plants against herbivores (Kirkeby-Thomsen 1998). Those, and other chemical compounds affect distribution of $A$. abietis galls within the crowns of host trees (McKinnon et al. 1999, Björkman 2000). Some results suggest that total nitrogen content in plant tissues reflects the physiological plant activity, so this parameter may work as a phytopathogenecity indicator (Paclt \& Hässler 1967).

The aim of this paper is to investigate $A$. abietis galls as regards: 1 ) vertical (crown layers) and horizontal (cardinal directions) distribution within spruce crowns, 2) deformation (bending) of shoots, 3) relationship between gall size and number of larval chambers. For discussion of the results of the first aim, we consulted papers in which chemical relations between gall development and chemical content of the host have been investigated. Some of our aims may seem to repeat the results given by Fidgen et al. (1994) and McKinnon et al. (1999), but at least two factors are different: 1) The host species. The abovementioned authors studied white spruces $(P$. glauca), while we studied Norway spruces (Picea abies (L.) H. Karst); 2) As A. abietis is considered to be of European origin, it should not be ignored that it may infest trees in Canada in a different manner than in Poland. And that could be related to USDA plant hardiness zones, defined on the basis of minimal temperatures of different regions. The investigated stands from Can- 
ada in studies by Fidgen et al. (1994) and McKinnon et al. (1999) were classified within the zone 5 a or below (Plant Hardiness Zones 2000 in the Online Atlas of Plant Hardiness Zones of Canada). The Norway spruce plantation of our study lies in the zone of 7 a (Heinze \& Schreiber 1984).

We hypothesize that: 1) "Taller spruce trees growing on the examined area have more galls on shoots than shorter spruce trees". Taller trees have more shoots to infest than the shorter ones. Within stands of different tree heights, they also are more insolated and thus A. abietis females prefer them. 2) "The galls occur mostly in the middle of crown". Since the upper crown is more exposed to harsh winter conditions, the fundatrices prefer the lower shoots of the middle layer to the lower ones. The lower shoots are overshadowed too much and do not provide enough nutrients for developing galls. 3) "Females induce galls on the southern side of tree crown more frequently than on other sides of the crown". The southern side has probably better insolation, positively influencing the amount of assimilates that are required for gall-induction and feeding of the larvae. 4) "Gall size depends on its placement within the crown and the type of the occupied shoot". 5) "Growing gall deforms the shoot". Larvae living in the gall compete for nutrients with themselves and the shoot. We claim that large galls deform shoots more often than small ones. By deformations we mean bending of the shoot with a developing gall. 6) "Both shoots, embraced totally or only partly by the gall, tend to be bent beyond the point where the gall developed". The shoot deformation seen as a bending behind the gall is a result of the competition between gall and plant tissues. The plant, in which the physiology is changed in order to form a gall, does not correctly develop its infested shoots. 7) "The number of larval chambers correlates positively with gall size".

\section{Material and methods}

The present studies were performed on a Norway spruce plantation, established on post-agricultural ground in the Experimental Forest "Zwierzyniec", which belongs to the Institute of Dendrology of Polish Academy of Sciences in Kór- nik, Poland (N: 52¹0'26”, E: 1851'9”). Observations were conducted in July 2011 and 2013. In 2011 the spruces were 6 years old and they were $0.5-2 \mathrm{~m}$ high. In 2013 all of the studied trees were measured with an accuracy of $1 \mathrm{~cm}$ (min $0.53 \mathrm{~m}$, max $4.43 \mathrm{~m}$, mean $2.65 \mathrm{~m}$ ). The trees were planted in rows with a distance of approximately $1.5 \mathrm{~m}$ between trees. In 2011 and 2013 we haphazardly investigated 10 and 8 rows, respectively. The first row of spruces is growing along a farmland, i.e. next to an open area. We did not investigate all of the rows, as we ignored the last rows near the forest border. We studied all of the trees growing in the investigated rows, observing their crowns from each side. We tried to find and describe all of the galls.

In both years we checked: 1) the number of A. abietis galls; 2) the size of the galls, by measuring their length along the long axis (electronic caliper, $0.1 \mathrm{~mm}$ accuracy); 3) the within-crown distribution: a) cardinal direction, b) part of crown (lower, middle, upper) by dividing the height into three equal parts, c) shoot (main/ lateral), where we considered the main shoot as: i) trunk, ii) shoots which make up the axis of the whorl branch; 4) the deformation of the shoot behind the gall (bent or not bent); 5) the extent of the shoot embrace by the gall (gall totally vs. partly embracing the shoot). In addition, in 2013 we haphazardly collected 37 galls from 23 trees, measured their length with electronic caliper and counted the number of chambers.

We performed statistical analyses by means of STATISTICA 10 software (StatSoft). Linear regression was used to characterize the relationship between tree height and the number of galls on a spruce tree and also to determine the relationship between the number of larval chambers and gall size.

In order to test the hypotheses of random distribution of galls in the four cardinal directions and part of the spruce crown, we recorded the location of the galls on each direction and crown part and used a chi-square test to verify statistical significance of the null hypothesis assuming that the proportion of the galls is equal in each direction $(25 \%)$ and in each part of the crown $(33 \%)$. The analyses were carried out independently for the study years. To test association between two variables (year and type of shoot) or (type of 


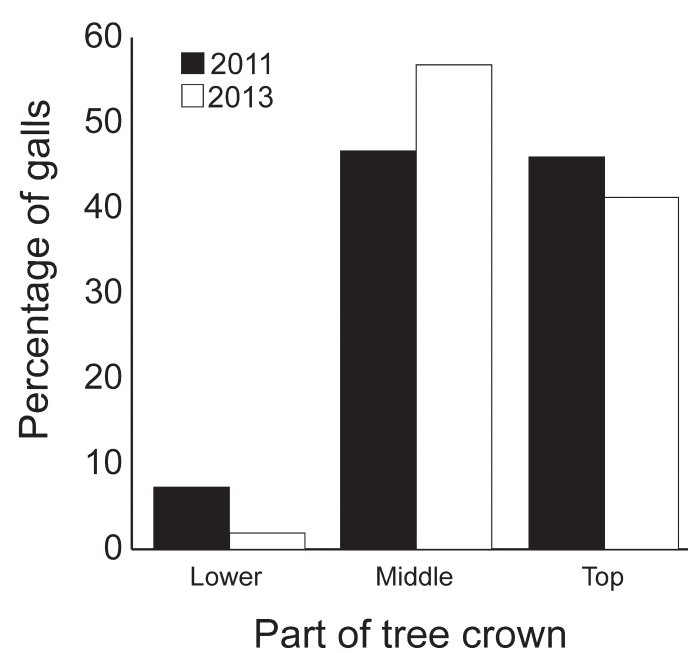

Fig. 1. Percentage distribution of Adelges abietis galls among three parts of spruce (Picea abies) crowns in 2011 and 2013.

shoot and type of deformation) we used Fisher's exact test. To analyse the relationship between the gall size (independent variable) and the extent of shoot embrace by the gall (dependent variable), we used simple logistic regression with outcome defined as 1: partial embrace of shoot, 0 : total embrace of shoot.

Mixed model ANOVA was used to analyze the influence of the year, crown position (or cardinal direction, or type of shoot), and interaction between them on the gall size. Trees were nested within a year. Year and crown position (or cardinal direction, or type of shoot) were considered to be fixed effects and tree was considered to be a random effect. Data was analyzed using ShapiroWilk test to test the assumption of normality. The Restricted Maximum Likelihood method was used for estimating the components of variance.

\section{Results}

We found 439 galls on 287 spruces (1.53 galls per tree) in 2011 and a little more, 521 galls on 221 trees (2.35 galls per tree) in 2013. The maximum number of galls (34) on one tree was found in

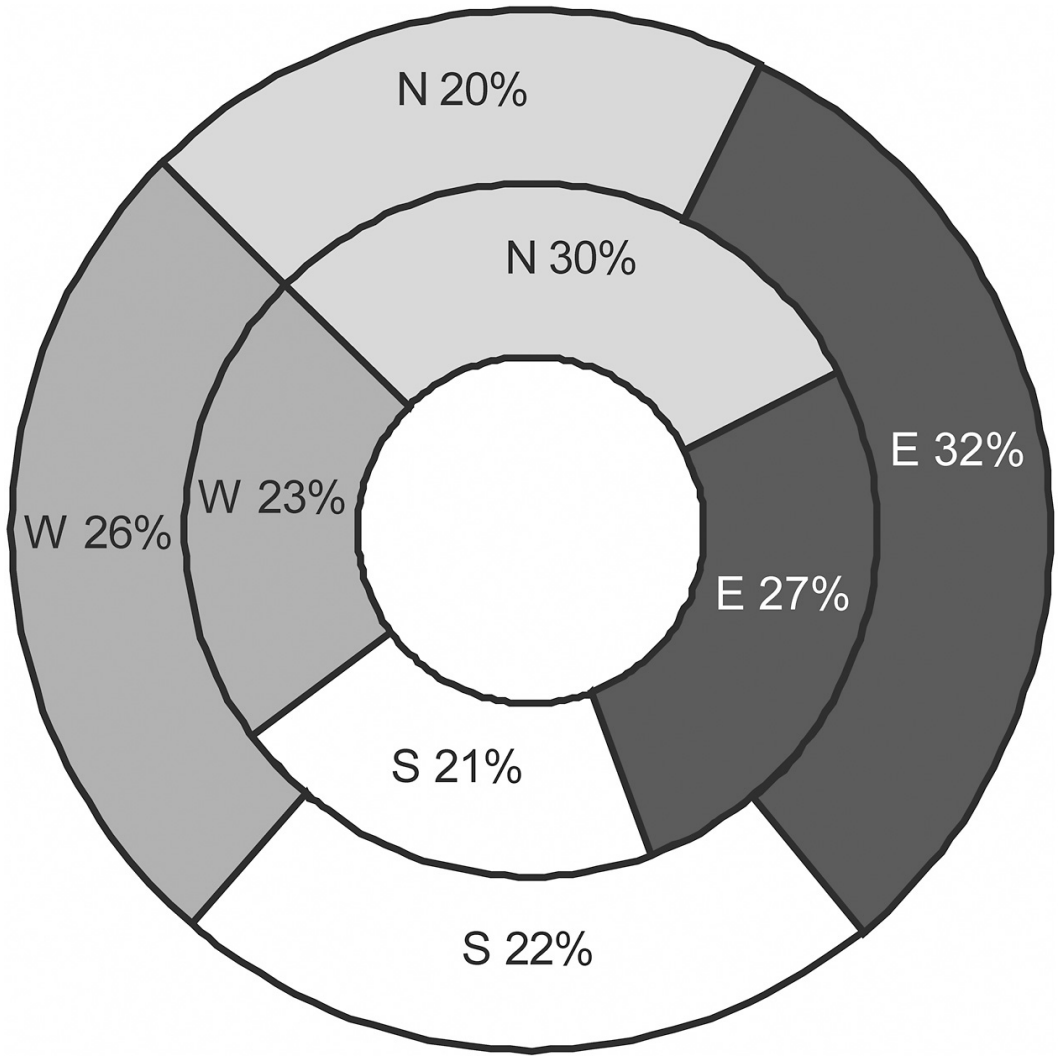

Fig. 2. Distribution of Adelges abietis galls among spruce (Picea abies) branches of the four cardinal directions. Outer ring for 2011, inner ring for 2013. 
2013. The smallest gall $(3.1 \mathrm{~mm})$ was found in 2013; in 2011 the smallest gall was $5.8 \mathrm{~mm}$ long. The average values were $20.0 \mathrm{~mm}$ (2011) and $17.6 \mathrm{~mm}$ (2013). We did not study the differences between galls developed among spruce trees growing inside of the plantation and on the border of it.

The spruce height was significantly associated to the number of galls, but the positive regression was weak $\left(y=-0.3303+0.0137 \mathrm{x} ; r^{2}=\right.$ $0.08, p<0.0001, n=221)$.

In 2011 the frequencies of galls occurring in the middle and upper parts of the crowns were similar ( $46.70 \%$ and $46.01 \%$ respectively), while we found more galls in the middle than the upper part (56.81\% and 41.27\%) in 2013 (Fig.1), in both years the lowest number of galls were in the lower parts of the spruce crown (for 2011: $\chi^{2}=$ 136.4, $d f=2, p<0.0001$, and for 2013: $\chi^{2}=250.3$, $d f=2, p<0.0001)$. We obtained significant differences between galls found in the four cardinal directions (for 2011: $\chi^{2}=14.8, d f=3, p=0.002$, and for 2013: $\left.\chi^{2}=11.1, d f=3, p=0.011\right)$. Most of the galls $(32 \%)$ were formed on the east side and least on the north side $(20 \%)$ in 2011 , while in 2013 most galls occurred on the north side (30\%), least on the south side (20\%) (Fig. 2). The open field was to the north.

The clearest difference between the years concerned infestation of the main vs. lateral shoots. Although there were more galls on the lateral shoots in both years $(67 \%$ in $2011,95 \%$ in 2013), the difference between the years was significant $\left(\chi^{2}=129.4, d f=1, p<0.0001\right)$.

Assessment of the deformation level was performed in 2013. Approximately $65 \%$ of shoots with galls had been deformed. Deformation was not connected with location within the tree crown, specifically neither with height $\left(\chi^{2}=5.6\right.$, $d f=2, p=0.061)$ nor with direction $\left(\chi^{2}=4.7, d f=\right.$ $3, p=0.20)$ of the infested shoot type. Level of shoot embrace showed a significant impact on deformation. When the shoot was totally embraced, the deformation (bending) was much rarer $\left(\chi^{2}=\right.$ $6.98, d f=1, p<0.0082)$. Although there was no significant influence of gall size on deformation (logistic regression, $\chi^{2}=2.02, p=0.16, n=521$ ), we are encouraged to claim otherwise. The gall size indirectly impacted the level of shoot embrace. Logistic regression showed that larger

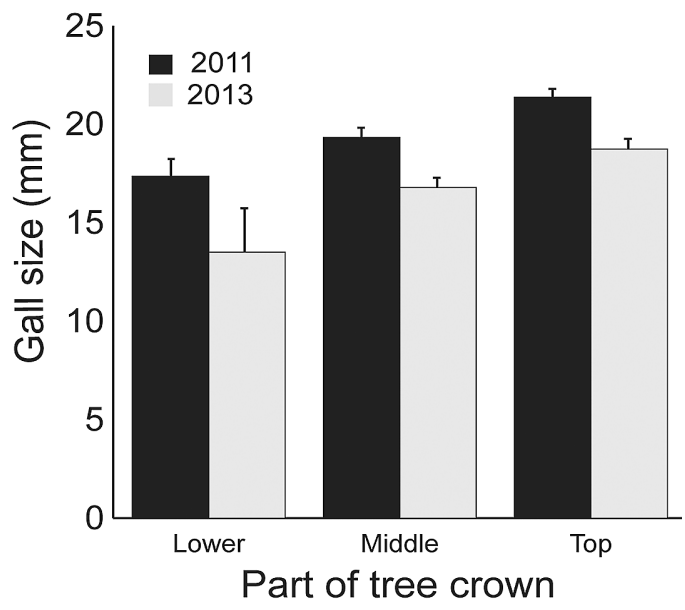

Fig. 3. Means (+ S.E.) of gall size of Adelges abietis in different parts of spruce (Picea abies) crowns in 2011 and 2013. Means with the same letter are not significantly different between treatments of the same year (ANOVA followed by Tukey HSD test).

galls totally embraced the shoot more frequently $\left[y=\mathrm{e}^{-0.86+0.06 \mathrm{x}} /\left(1+\mathrm{e}^{-0.86+0.06 \mathrm{x}}\right), x=\right.$ gall size, $\mathrm{y}=$ level of gall embrace, $\chi^{2}=13.95, p<0.001 ; n=$ 521].

Gall size differed between the years $\left(\mathrm{F}_{1,567.1}=\right.$ 9.19, $p=0.0025)$ and the shoot type $\left(\mathrm{F}_{1,884.8}=\right.$ 9.01, $p=0.0028)$, while their interaction was not significant $\left(\mathrm{F}_{1,884.8}=0.08, p=0.78\right)$. The galls on the main shoot were on average $3 \mathrm{~mm}$ (15\%) longer. In that analysis, the location of the galls within the tree crown could not be included. Therefore, in another analysis of variance, gall size differed both between the years $\left(\mathrm{F}_{1,533.3}=9.18, p=\right.$ $0.0026)$ and among the locations within the crown $\left(\mathrm{F}_{2,917.7}=23.29, p<0.0001\right)$ but there was no interaction $\left(\mathrm{F}_{2,917.7}=0.18, p=0.82\right)$ (Fig. 3). As shoot direction could not be included in the above analyses, in still a third analysis of variance, gall size did not differ among shoot directions $\left(\mathrm{F}_{3,881,7}=0.19, p=0.90\right)$, but again did so between the years $\left(\mathrm{F}_{2,273.5}=23.12, p<0.0001\right)$, whereas the direction-by-year interaction was not significant $\left(\mathrm{F}_{3,8817}=1.67, p=0.17\right)$. We did not find any statistically significant relationship between gall size and spruce height $\left(r^{2}=0.003, p=\right.$ 0.2 ). Larger galls had more larval chambers (Fig. 4). 


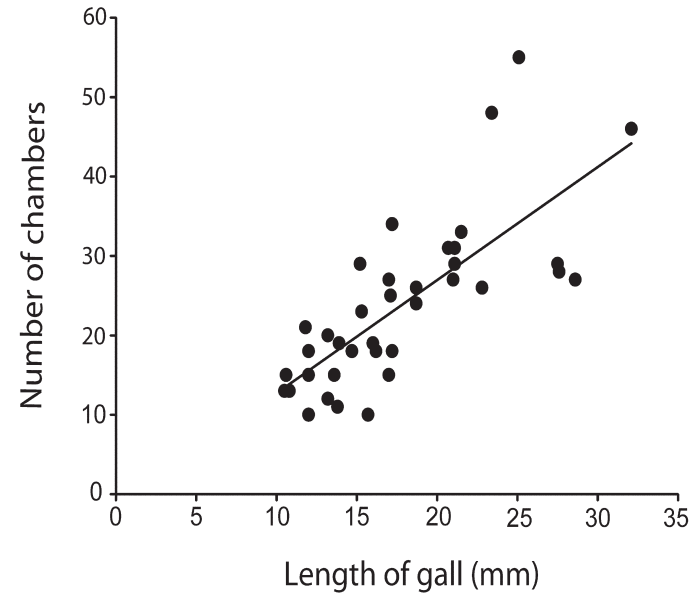

Fig. 4. Relationship between gall size and number of larval chambers of Adelges abietis on spuce (Picea abies) branches. $\mathrm{y}=-1.5204+1.4244 \mathrm{x}, p<0.0001$, $r^{2}=0.57$.

\section{Discussion}

The main results of our study consider the relationships between gall size, its influence on shoot deformation (bending) and shoot embracing by a gall. Although we could not statistically affirm a positive impact of small galls on shoot bending, we found that galls partially embracing the shoots bend the shoots significantly more often than larger galls. Since our studies showed that small galls embrace the shoots partially and the shoots embraced partially are more often bent, we are entitled to claim that small galls bend the shoots more often than large galls. Below we discuss each of our hypotheses enunciated in the Introduction section.

First, according to the significant, though weak, relationship between the number of galls and height of spruce, the adelgids more willingly infest taller trees. This may be related to: a) tall spruces have more shoots available to infest (colonisation by accident) and moreover they cover the shoots of lower trees; b) A. abietis is light-attracted and has a positive phototaxis (insect-dependent colonization by actively selecting tall trees), i.e. the insects avoid tissues which have limited ability to perform photosynthesis due to being overshadowed. Crawlers of Adelges piceae (Ratzeburg) show strong phototaxis during the early phase of life (Carrow 1961). Similar trend is observed for the larval stage called progrediens aptera of Dreyfusia nordmannianae Eckstein (Kirkeby-Thomsen 1998). Furthermore the largest galls develop in the upper layer of the tree crowns (Fig. 3).

Second, we showed that the number of larval chambers in a gall correlates positively with the gall size. Similarly, it has been confirmed in earlier studies that large galls produce more offspring than small ones (Björkman 2000, Sopow \& Quiring 2001). Shoot quality is associated with its size, distance to other shoots and number of needles (which is positively correlated with the number of chambers (Ozaki 2000)). Since large galls occur more often on large shoots that are rich in nutrients (Dorchin \& Freidberg 2004, Flaherty \& Quiring 2008), and the gall size correlates positively with the number of chambers, large shoots allow more offspring. We claim that this reflects both the quality of the inducing mother and the shoot, and these two elements cannot be treated separately. In our opinion, counting the chambers is a quick method to assess the gall and mother quality alongside more accurate methods, such as measuring the volumes of chambers or the number of progeny.

Third, we showed that A. abietis avoid the lower part of crowns, but in 2011 the percentage of galls inhabiting this part was 3.8 times higher than in 2013 (7.29\% and $1.92 \%$ respectively). Lower twigs of tall and dense spruces are not easily accessible, and obtain little light. It is anticipated that developing galls limit leaf-size due to competition for resources (Rehill \& Schultz 2001). In 2011, the percentage of galls in the lower crown part was probably higher, due to greater shoot accessibility, because the trees were then smaller. Moreover, short spruces might have relatively more suitable shoots, not because of sun exposition, but because of their size. With a limited number of shoots on young plantations it is possible that shoot rejections by the insects were not as strict as for older and taller trees. In 2013, most infested shoots were in the middle part. This corresponds with the results for $A$. abietis investigated on Picea glauca (Fidgen et al. 1994, McKinnon et al. 1999) but disagrees for A. tsugae (Evans \& Gregoire 2007). Accordingly, as regards crown layers, A. abietis induces 
its galls on young Norway spruces similarly in our study area as on white spruces (Fidgen et al. 1994, McKinnon et al. 1999) within a wide range of the USDA plant hardiness zones in Canada.

For A. abietis, McKinnon et al. (1999) showed a negative correlation between the number of galls on a shoot and nitrogen content in spring foliage of spruces. Additionally, Niinemets (2007) showed that the nitrogen allocation within the tree crown happens due to the aging of the lower shoots. Such allocation of nitrogen (and other elements) may help in understanding the distribution and ecology of galling animals. If spruce trees allocate nitrogen from their lower parts to the higher ones, this would explain the limited distribution of galls in the lower parts. In light of the above negative correlation, it can be assumed that nitrogen is allocated from lower crown to higher, but also the middle crown nitrogen content allows successful gall-induction. These independent results should be taken into consideration in the discussion of the preference of $A$. abietis toward the middle part of the crown. Indeed, the distribution of galls in the middle crown and upper crown were similar in 2011, but it must be highlighted that the trees were short $(0.5-2 \mathrm{~m})$ and this could play a considerable role in such distribution. Nevertheless, the results for older trees showed a significant difference between the middle and upper crown, even if those two layers were dominant in terms of gall distribution when compared with the lower crown. We claim that more factors than investigated up until now play their roles in the distribution and number of galls.

Our finding that larger galls occur in the upper layer leads to another question. Why fundatrices do not focus their efforts on shoots of this layer? Possibly it is a matter of diverse strategies in securing reproduction. It means that although more offspring would emerge from larger galls on the upper crown, there is a higher risk that wintering females will get killed by low temperatures associated with winds at the top of trees. Furthermore, the insects can be killed by high temperatures when exposed to the sun. To prevent total death, some fundatrices occupy the middle layer of the crown, where they are not exposed as much to the harsh conditions. The lower crown can protect the fundatrices from low temperatures only in mild regions, while cold air is heavy and accumulates in this layer. In addition, among the fundatrices feeding on the lower crown shoots there are individuals which fell from shoots higher above before starting a gall-induction. Fundatrices are sessile and do not leave the spot where they overwintered and started gall-induction (Redfern 2011b). Note that fundatrices are wingless, while gallicolae (second life stage, emerging from the gall) are winged females which are parents of the fundatrices. Thus, the gall position is determined by both life-stages (gallicolae lay eggs nearby while they are not intensive fliers, and fundatrices disperse in a limited range). As most galls develop in the middle crown, the galls produced in the upper crown may play a secondary role. On the other hand, they may be of considerable importance (after a mild winter) since they produce more offspring.

Similarly to A. tsugae (Evans \& Gregoire 2007), A. abietis does not prefer south-facing shoots (Fig. 2). In 2011 we found most galls on the east side and in 2013 on the north side, i.e. in the directions of smaller insolation. This may be related to avoidance of too high insolation, resulting in temperatures killing larvae or increasing predation (Evans \& Gregoire 2007), even though higher efficiency of photosynthesis, and therefore higher amounts of assimilates for production of galls and larval feeding would be predicted for the south-facing shoots. Thus, position of the galls on the shoots with smaller insolation probably enhances the competition for resources between galls and shoots. Contrary to summer time, south side avoidance may lead to decreasing survival of wintering larvae. Evans and Gregoire (2007) paid attention to the different thermic aspects during the winter and the summer. Undeniably, higher sun exposure during cold periods prevents deaths of wintering larvae.

We suspected that the lateral shoots would cover the main ones to some extent, competing for light and producing galls of similar size. It has already been shown that conifers perform structural and physiological changes in the needles and on shoot/crown level, adapting themselves to light conditions (Stenberg et al. 2001, Cescatti \& Zorer 2003, Niinemets 2007). Räim et al. (2012) observed a decrease of photosynthetic rate in $P$. abies along with age. We found that galls which 
developed on the main shoots were significantly larger than those on lateral shoots. Probably there are more assimilates in main shoots than in the lateral ones. A second possibility is the more advantageous concentration of repellents and/or attractants in main shoots.

Fourth, we showed that small galls embrace the shoots partially and deform shoots more often than larger galls. Large gall, embracing the shoot totally or almost totally, prevents deformations of the shoot (manifested as bending), because effects of the gall are equal from all sides of the shoot. These findings reject our hypothesis of large galls deforming shoots. It is possible that large galls also tend to deform the shoots, but the developing gall does not bend the branch. A female can produce a gall on a large branch/module only if it is able to inject a high enough dose of stimulus, because large modules can overpower the gall-induction if the dose is too small (Flaherty \& Quiring 2008). If a female is successful in initiating a gall in a large branch, the gall will grow larger than in a small branch, because a large branch has fast-dividing cells (Dorchin \& Freidberg 2004, Flaherty \& Quiring 2008), which are able to overcome the needs of developing galls.

\section{Conclusions}

In the studied range of Norway spruce heights, it can be concluded that the taller spruces had more galls of $A$. abietis on one-year old shoots than shorter ones. Short spruces showed that galls are distributed mostly and evenly in the middle and upper crown (results for 2011). In 2013, however, most galls grew in the middle part of the crown. Possibly, the examined spruces which were considerably taller than in 2011, allocated nitrogen differently between crown parts, impacting on the vertical distribution of galls. Adelges abietis females did not prefer south-facing shoots for gall-induction. They might have thus avoided higher temperatures and predation. However, they seemed to prefer east-facing (maximum for 2011, the second largest percentage in 2013) or even north-facing (maximum for 2013) shoots. Apparently, those directions secured enough sunlight and heat to the shoots. Maybe the eastern sunlight was warming up the galls in the mornings, as well as the fundatrices, which had overwintered and had started a gall-induction.

Gall size, which correlated positively with the number of gall chambers, was not related to Norway spruce height and cardinal direction. Large galls occurred more frequently on the main shoots. Small galls, by only incompletely embracing the stem, deformed infested shoots more often than large ones.

Acknowledgements. We gratefully thank two reviewers for their useful comments and suggestions and Jadwiga Fibakiewicz for language corrections of our manuscript. This study was supported by University of Zielona Góra and Institute of Dendrology Polish Academy of Sciences.

\section{References}

Björkman, C. 2000: Interactive effects of host resistance and drought stress on the performance of a gall-making aphid living on Norway spruce. - Oecologia 123: 223-231.

Carrow, J. R. 1961: Some effects of host tree nutrition on establishment and survival of the balsam woolly aphid, Adelges piceae (Ratz.). A thesis submitted in partial fulfilment of the requirements for the degree of Master of Science, The University of Toronto, Department of Zoology. 73 pp.

Cescatti, A. \& Zorer, R. 2003: Structural acclimation and radiation regime of silver fir (Abies alba Mill.) shoots along a light gradient. - Plant, Cell and Environment 26: 429-442.

Chilima, C. H. \& Leather, S. R. 2001: Within-tree and seasonal distribution of the pine woolly aphid Pineus boerneri on Pinus kesiya trees. - Agricultural and Forest Entomology 3: 139-145.

Dorchin, N. \& Freidberg, A. 2004: Sex ratio in relation to season and host plant quality in a monogenous stemgalling midge (Diptera: Cecidomyiidae). - Ecological Entomology 29: 677-684.

Evans, A. M. \& Gregoire, T. G. 2007: The tree crown distribution of hemlock woody adelgis, Adelges tsugae (Hem., Adelgidae) from randomized branch sampling. - Journal of Applied Entomology 131(1): 26-33.

Fidgen, J. G., Teerling, C. R. \& McKinnon, M. L. 1994: Intra- and inter-crown distribution of the Eastern Spruce Gall Adelgid, Adelges abietis (L.), on young white spruce. - The Canadian Entomologist 126(5): 11051110 .

Flaherty, L. \& Quiring, D. 2008: Plant module size and dose of gall induction stimulus influence gall induction and galler performance. - Oikos 117: 1601-1608.

Giertych, M. J., Jagodziński, A. M. \& Karolewski, P. 2013: Spatial distribution of Cynips quercusfolii (Hy- 
menoptera: Cynipidae) galls on leaves and within the crowns of oak trees. - European Journal of Entomology 110(4): 657-661.

Havill, N. P. \& Foottit, R. G. 2007: Biology and evolution of the Adelgidae. - Annual Review of Entomology 52: 325-349.

Heinze, W. \& Schreiber, D. 1984: Eine neue Kartierung der Winterhärtezonen für Gehölze in Europa. - Mitteilungen der Deutschen Dendrologischen Gesellschaft 75: 11-56.

Jaśkiewicz, B., Kmieć, K. \& Golan, K. 2002: Ochojnikiszkodniki świerków. - Ochrona Roślin 10: 17-18. [In Polish.]

Kirkeby-Thomsen, A. 1998: Host plant resistance in $A$. nordmanniana to D. nordmannianae. — Danish EPA, Pesticides Research 39.

Kosibowicz, M. 2008: Ocena zdrowotności upraw i młodników na terenach poklęskowych w Górach Izerskich. - Problemy zagospodarowania ziem górskich 55: 85-97. [In Polish.]

McKinnon, M. L. \& Quiring, D. T. \& Bauce, E. 1999: Influence of tree growth rate, shoot size and foliar chemistry on the abundance and performance of a galling adelgid. - Functional Ecology 13: 859-867.

Miller-Pierce, M. R. \& Preisser, E. L. 2012: Asymmetric priority effects influence the success of invasive forest insects. - Ecological Entomology 37: 350-358.

Niinemets, Ü. 2007: Photosynthesis and resource distribution through plant canopies. - Plant, Cell and Environment 30: 1052-1071.

Ozaki, K. 2000: Insect-plant interactions among gall size determinants of adelgids. - Ecological Entomology 25: 452-459.

Paclt, J. \& Hässler, J. 1967: Concentration of nitrogen in some plant galls. - Phyton 1: 173-176.
Ravn, H. P., Havill, N. P., Akbulut, S., Foottit, R. G., Serin, M., Erdem, M., Mutun, S. \& Kenis, M. 2013: Dreyfusia nordmannianae in Northern and Central Europe: potential for biological control and comments on its taxonomy. - Journal of Applied Entomology 137: 401-417.

Räim, O., Kaurilind, E., Hallik, L. \& Merilo, E. 2012: Why does needle photosynthesis decline with tree height in Norway spruce? - Plant Biology 14: 306-314.

Redfern, M. 2011a: Erinea, Folds and Rolls. — In: Redfern, M. (ed.), Plant galls: 78-122. Collins, London. 564 pp.

Redfern, M. 2011b: Big Buds, Cigars, Pineapples and Rosettes. — In: Redfern, M. (ed.), Plant galls: 153-176. Collins, London. 564 pp.

Rehill, B. J. \& Schultz, J. C. 2001: Hormaphis hamamelidis and gall size: a test of the plant vigor hypothesis. Oikos 95: 94-104.

Sano, M. \& Ozaki, K. 2012: Variation and evolution of the complex life cycle in Adelgidae (Hemiptera). - Entomological Science 15: 13-22.

Sopow, S. L. \& Quiring, D. T. 2001: Is gall size a good indicator of adelgid fitness? - Entomologia Experimentalis et Applicata 99: 267-271.

Sopow, S. L., Shorthouse, J. D., Strong, W. \& Quiring, D. T. 2003: Evidence for long-distance, chemical gall induction by an insect. - Ecological Letters 6: 102105.

Stenberg, P., Palmroth, S., Bond, B. J., Sprugel, D. G. \& Smolander, H. 2001: Shoot structure and photosynthetic efficiency along the light gradient in a Scots pine canopy. - Tree Physiology 21: 805-814. 